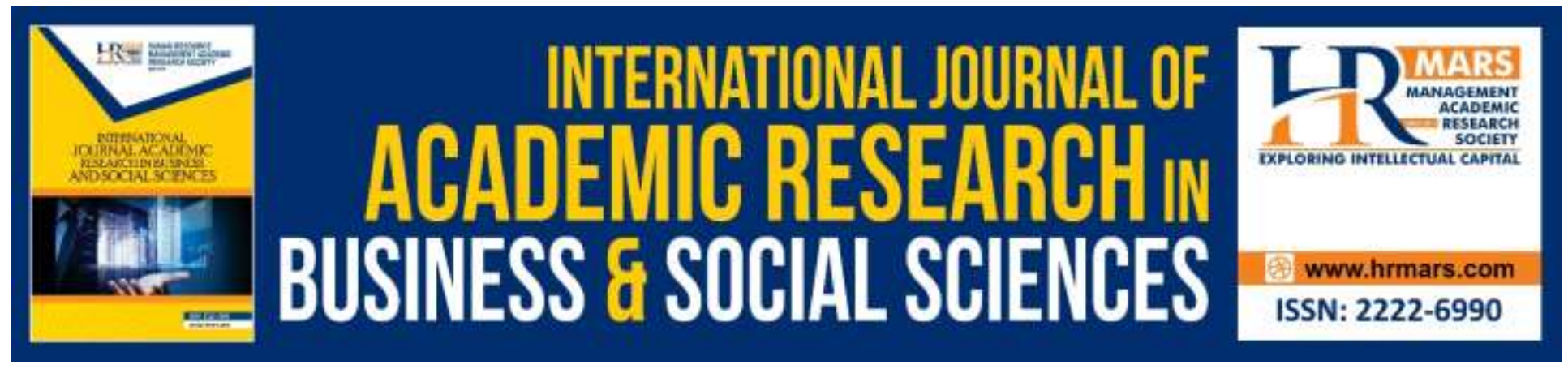

\title{
Investigating the Psychological Determinants of the Intention to Use E-Hailing Services
}

Nur Zaimah Ubaidillah, Lim Sien Nar, Rosita Hamdan, Audrey Liwan, and Farhana Ismaiı

To Link this Article: http://dx.doi.org/10.6007/IJARBSS/v9-i11/6571 DOI: 10.6007/IJARBSS/v9-i11/6571

Received: 12 October 2019, Revised: 30 October 2019, Accepted: 14 November 2019

Published Online: 28 November 2019

In-Text Citation: (Ubaidillah et al, 2019)

To Cite this Article: Ubaidillah, N. Z., Nar, L. S., Hamdan, R., Liwan, A., and Ismail, F. (2019). Investigating the Psychological Determinants of the Intention to Use E-Hailing Services. International Journal of Academic Research in Business and Social Sciences, 9(11), 496-512.

Copyright: (c) 2019 The Author(s)

Published by Human Resource Management Academic Research Society (www.hrmars.com)

This article is published under the Creative Commons Attribution (CC BY 4.0) license. Anyone may reproduce, distribute, translate and create derivative works of this article (for both commercial and non-commercial purposes), subject to full attribution to the original publication and authors. The full terms of this license may be seen at: http://creativecommons.org/licences/by/4.0/legalcode

Vol. 9, No. 11, 2019, Pg. 496 - 512

Full Terms \& Conditions of access and use can be found at http://hrmars.com/index.php/pages/detail/publication-ethics 


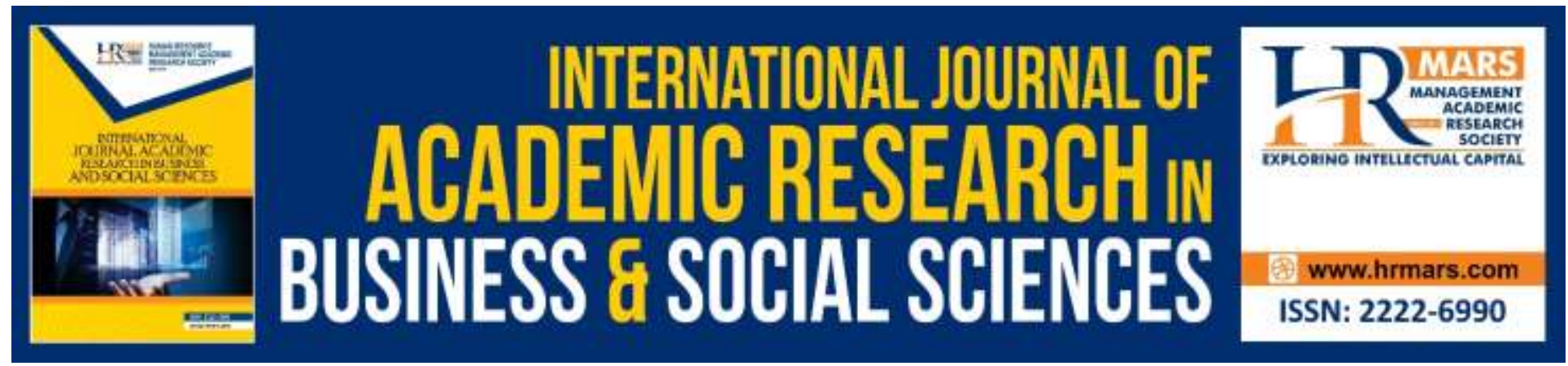

\title{
Investigating the Psychological Determinants of the Intention to Use E-Hailing Services
}

\author{
Nur Zaimah Ubaidillah, Lim Sien Nar, Rosita Hamdan, Audrey \\ Liwan, and Farhana Ismail
}

Faculty of Economics and Business, Universiti Malaysia Sarawak, Sarawak, Malaysia.

\begin{abstract}
The transportation industry has changed rapidly in recent years. The increased availability of location data and the increasing number of applications, together with other forms of information and communication technologies (e.g., e-commerce, telecommunication), are transforming transportation supply and demand in numerous ways. The integration of the global mobile positioning system (GPS) and electronic payment along with the continuous need for flexible travel has led to the Grab e-hailing service becoming one of the most prominent ondemand private driver platforms in the Asian region. Hence, this study aimed to examine the behavioral intentions of Generation Z to use the Grab e-hailing service. The study used 330 samples collected from undergraduate students in Malaysia. The collected data were analyzed using multiple regression analysis. The results showed that there is a significant relationship between the perceived price and advantages, perceived convenience, and perceived accessibility towards the behavioral intention to use the Grab e-hailing service. This research study offers useful and essential information for stakeholders to achieve a further understanding of the psychological determinants to address the needs of special interest group of end-users.
\end{abstract}

\section{Introduction}

In the 21st century, various internet-based technologies, including information and communication technologies (ICT), have emerged and expanded into consumers' daily lives. Digital technology, especially mobile technology, plays a crucial role in changing consumer lifestyles, especially for the younger generation. The presence of ICT also creates new opportunities for new businesses to meet customers' needs, such as online businesses and mobile technology-based businesses. The innovation in mobile technology has led to a rapid expansion in the transportation industry. Meanwhile, the integration of the global mobile positioning system (GPS) and electronic payment along with the continuous need for flexible 
travel has caused the Grab e-hailing service to become one of the most prominent on-demand private driver platforms in the Asian region. The convenient, inexpensive and safe on-demand service provided by the Grab e-hailing service enables a more flexible and reliable mode of transportation, particularly for road end-users who prefer riding in a privately-owned vehicle. Furthermore, the high level of private vehicle-based motorization in many urban cities in developing Asian countries has encouraged greater intention among road users to opt for the Grab e-hailing service rather than take other modes of transport, such public buses or trains.

Currently, the Grab e-hailing service is the primary e-hailing provider for consumers in Malaysia. It is available in Malaysia's main cities, such as Kuala Lumpur, Penang, Seremban, Ipoh, Kuantan Johor, Kuching and others. In urban cities, difficulties in obtaining parking spaces and traffic congestion are other factors that affect consumer intention to use e-hailing services rather than private vehicles. As Generation $Z$ is a growing customer base and is less interested in owning a car compared to previous generations, the e-hailing service offers an optimal solution. Past studies have been conducted regarding the importance of e-hailing services as a substitute for traditional taxi services and other public transport. However, there are only very limited studies being conducted in this field. Therefore, this study aims to bridge the gaps by investigating the behavioural intention to use the Grab e-hailing service, particularly in relation to Generation $Z$. The subsequent section in this paper explores the review of literature where several factors influencing Generation Z's intention to use the Grab e-hailing service are identified and then proposes a conceptual framework, data analysis and conclusion.

\section{Literature Review}

\section{Technology acceptance model}

For this paper, the technology acceptance model (TAM) is used as the theoretical framework to investigate the intention of Generation Z consumers to use the Grab e-hailing services. According to Kock (2014), the TAM model is an information system theory and was first introduced by Fred Davis in 1987. TAM can be explained as an individual's intention to adopt new technology, which is directly influenced by the perception of its ease of use and usefulness (Andra \& Rejikumar, 2017). TAM is adapted from the theory of reasoned action (TRA) and theory of planned behavior (TPB), which specify the casual linkage and belief sequence flows as well as the intention to use information systems and technology. Primarily, TAM is used to analyze the factors and effects of technology's perceived usefulness and convenience. A consumer's intention to use the technology and the perceived usefulness of the technology are thus directly influenced by the individual's attitudes. According to Davis (1989), TAM claims that the user acceptance of technology can be used to determine both the perceived ease of use and perceived usefulness of the technology. A significant amount of research has evaluated the intention to use technology, the actual usage of technology, and the effect of customer perceptions towards technology, referring to the perceived ease of use and perceived usefulness of technology (Dunn and Tucker, 2013). 
TAM states that an individual's belief influences their attitude towards the usage of information technology and systems. In TAM, the perceived ease of use of technology and its perceived usefulness are the main determinants of actual system use. According to Davis (1989), perceived usefulness is the degree to which someone trusts that technology will enhance their work performance based on the TAM system. Meanwhile, perceived ease of use is the degree to which someone can use technology without effort according to the TAM system. The attitude towards use evaluates the users' desirability regarding the use of an information system. Behavioral intention refers to the perceived likelihood of a person's willingness to try a product. According to TAM, behavioral intention is influenced by the attitude to use and perceived usefulness. Perceived usefulness and perceived ease of use directly affect the attitude to use, whereby perceived usefulness is directly impacted by perceived ease of use. Therefore, perceived usefulness and perceived ease to use are the main indicators affecting the attitude to use, the behavioral intention to use, and finally, the actual system use. However, since there are very few psychological studies on e-hailing services, this study only partially adapts the components of TAM in the development of the conceptual framework; that is, the perceived usefulness of the Grab e-hailing service is further elaborated within the conceptual framework.

\section{Generation Z}

There is a broad definition of post-millennial Generation Z. According to Tapscott (2009), Generation Z refers to those who are born between the mid-1990s and early 2010s. On the other hand, Turner (2015), defined Generation Z as those who are born between 1993 and 2005. One of the most distinct characteristics of Generation $\mathrm{Z}$ is that they spend more time with electronics and being on the Internet compared to previous generations, such as the Baby Boomers, Generation X and Millennials (Eckleberry-Hunt et al., 2018). Generation Z is also considered the first generation that has access to a wide scale of digital communication technology. This is further underlined by the importance of smartphones and the average of 6.5 hours spent daily by Generation Z on electronic devices (Dwidienawati, 2018). Against this background, it is imperative to investigate the usage of the Grab e-hailing service using the case study of Generation Z.

\section{Intention to use Grab}

Intention can be described as "a thing intended, a plan or aim". The Grab e-hailing service is a new and innovative technology that connects drivers and passengers via a mobile application. Grab is the largest ride-hailing service company in Malaysia and provides a better service compared to traditional taxi services. The on-demand service, convenience and multiple choices offered by the Grab e-hailing service as well as the cost savings are the crucial elements that have led Grab to succeed in the Southeast Asian market. In Malaysia, $65 \%$ of consumers prefer to take a Grab car rather than a traditional taxi because they deem the former to be more trustworthy, more comfortable and safer than other alternatives. Due to technological advances, the Grab ehailing service is a frequently used on-demand service due to its availability, accessibility, and fast and flexible service, especially in urban areas. This leads to the customer intention to choose 
the Grab e-hailing service instead of a traditional taxi service. Rayle et al. (2014) conducted a survey and showed that $25 \%$ out of 313 respondents stated that the Grab service was more comfortable, more convenient and gave a better experience. In addition, the Grab company often gives out promotion codes and coupon redemptions to attract price-sensitive customers another key indicator for the increase in consumers' intention to choose the Grab e-hailing service. In addition, Grab Share is an on-demand carpooling service that matches consumers who are heading in the same direction, helping to solve the traffic congestion problem during peak hours while enabling consumers to enjoy lower fares. This can further increase consumers' intention to use the Grab e-hailing service.

\section{Conceptual Framework}

This research focuses on an investigation of the intention of Generation Z to use the Grab e-hailing service in UNIMAS. The proposed conceptual framework is adapted according to past studies related to the use of ICT-based applications - not necessarily in relation to the Grab ehailing application - and to suit the research needs. Hereby, four factors will be investigated, namely perceived safety and security $(\mathrm{H} 1)$, perceived price advantages $(\mathrm{H} 2)$, perceived convenience $(\mathrm{H} 3)$, and perceived accessibility $(\mathrm{H} 4)$, to guide the exploration of the intention of Generation Z to use the Grab e-hailing service.

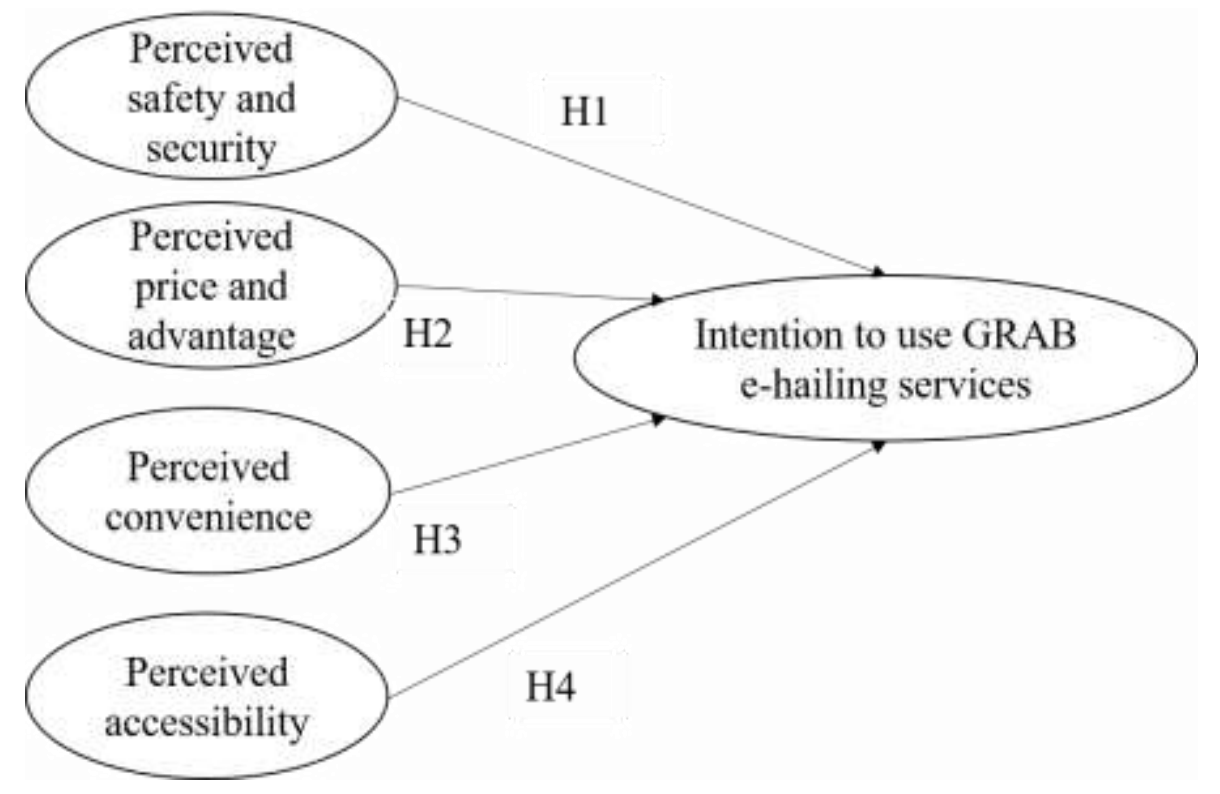

Hypothesis 1 (H1): There is a significant relationship between perceived safety and security and the intention of Generation Z to use the Grab e-hailing service.

The Grab e-hailing service emphasizes customer safety and security on every ride. Therefore, it has implemented some initiatives to protect passengers' safety. For example, Grab drivers have to prove their certificate of liability insurance and must have no criminal record. 
They must also comply with all traffic laws, rules and regulations. In addition, the car registered for the Grab e-hailing service must fulfil certain conditions, e.g. its age must not exceed five years and it must meet the minimum fuel efficiency standards as well as data reporting requirements (Ngo, 2015). According to Grab (2017) the "Introducing, our New Safety Measures" (2017), an inapp "emergency button" feature was added to directly connect customers to MERS 999 in cases of emergency. Furthermore, an in-car camera was added to monitor the inside car safety of every Grab ride. Beyond personal safety, the passenger's privacy concerns are also an important factor. In the Grab e-hailing service, customers can select their payment method, paying either by cash or by bank card according to the customer's preference. To avoid incurring extra charges from the drivers, Grab encourages customers to use the bank card payment method rather than cash. In relation to this, Grab promises that the personal data and information are kept in a safe and secure condition. Furthermore, with Grab acting as an intermediary connecting drivers and passengers using the app, customers can learn more about individual drivers and evaluate them for future improvement.

Hypothesis 2 (H2): There is a significant relationship between perceived price and advantages and the intention of Generation $Z$ to use the Grab e-hailing service.

Perceived price and advantages refer to the prices that consumers are willing to pay for particular products or services based on their perception towards them. Price is a vital indicator that affects affordability in relation to the fares charged and the service provided in the transportation industry (Button \& Hensher, 2001). Most consumers choosing the Grab e-hailing service do so as the price is lower and offers them better customer value. Any high fare rate is shown in the Grab app before the customer requests a pickup, allowing the users to change their minds if the rate is too high, which is an added advantage. Promotion codes also have a great impact on the price of taking a Grab car. Such promotions aim to convince the target market to buy a certain product or service using the discount, advertising and reward methods. A promotion affects consumers' thinking and emotions when they purchase a product or service. For the Grab e-hailing service, coupon redemption and promotion codes are the tools used in sales and promotion to attract more consumers. To compete with other ride-hailing service competitors, the Grab e-hailing service offers such promotion codes through the Grab app for consumers to enjoy lower fares. Promotion and price are vital elements of the marketing mix that affect customer satisfaction regarding the Grab e-hailing service. Besides promotion codes, Grab also offers rewards and exclusive deals to consumers to generate customer loyalty. Examples of Grab rewards include discounts on food and beverages, shopping and others. Hence, price is a vital factor that influences consumers, especially Generation Z, in their intention to use Grab.

Hypothesis 3 (H3): There is a significant relationship between perceived convenience and the intention of Generation Z to use the Grab e-hailing service. 
According to Berry, Seiders, and Grewal (2002), time and effort determine the convenience of a product or service. A product or service is considered convenient when it saves time for users. Brown (1990) stated that there are five dimensions of the convenience of a product or service, namely time, place, use, acquisition, and execution. Convenience can also be defined as the perceived time and energy taken to achieve a task goal. In the sharing economy, perceived convenience is an important factor influencing consumer behaviour. Convenience affects shopping motivation, which acts as a determinant of consumers' intention to shop online (To, Liao and Lin, 2007). Hossain and Prybutok (2008) mentioned that convenience encompasses ease of use and usefulness. Thus, there is a positive relationship between perceived convenience and the TAM model. Grab offers various types of ride-hailing service, including GrabTaxi, GrabBike, GrabCar, GrabShare, GrabHitch, GrabShuttle and GrabCoach, in different countries. Consumers are thus able to select their preferred Grab service based on their needs and wants. Waiting time is another common reason for the consumer tendency to use the Grab service, after the ease of payment, whereby the travel speed and the distance between the car's current location and the pick-up location will influence the customer's waiting time. According to Carazan, Chow, Pham, Roswell and Sun (2016), the Grab e-hailing service not only saves money but also saves time. Unlike public transportation, such as bus or train, which follows a fixed itinerary, the Grab e-hailing service allows consumers to book a ride at any time. In addition, Grab cars drop off their customers at the point of destination, meaning consumers can reduce the time needed to walk to their destination compared to other public transportation methods.

Hypothesis 4 (H4): There is a significant relationship between perceived accessibility and the intention of Generation Z to use the Grab e-hailing service.

Accessibility is "the extent which enable a group of individuals to reach destination or activities through transport modes" according to Geurs and Ritsema van Eck (2001). This definition implies that accessibility is closely linked to the ability to move, i.e. mobility. A person's level of access to transportation is easily influenced by individual characteristics in terms of their needs, abilities and opportunities. Grab offers a range of transportation services and associated payment methods through one mobile app, which has been downloaded over 90 million times. User-friendliness is an added advantage of the Grab application (Geradin, 2015). The Grab app transmits the current location of the requested Grab car, and the customers can track the process via their smartphone, which is considered preferable to the uncertainty of waiting for a traditional taxi. Passengers can also provide special requests or detailed information for the drivers through Grab Chat, which is available in the Grab mobile application to ensure better communication between drivers and passengers.

\section{Methodology}

Population and Sampling Procedures 
The sample size is determined according to the following formula. The population size, margin of error, confidence level and standard deviation need to be identified before the appropriate sample size can be calculated. The total number of students in the Faculty of Economics and Business (FEB) for 2019 is 1,918. However, the research focuses only on Year 3 undergraduate students in FEB in UNIMAS, meaning the population size is 522 students. The common standard deviation is set to 0.05 in most studies, and the common margin error is $5 \%$ for categorical data. The $z$-score is 1.96 , and the confidence level is $95 \%$. According to the calculation, a minimum of 305 samples of FEB year three undergraduate students were needed to participate in the questionnaire survey. As a result, 330 sets of the questionnaire survey were obtained after approximately 350 sets were distributed to potential respondents to ensure validity and consistency.

\section{Statistical Analysis}

The data obtained from the 330 respondents were compiled, categorized, verified and appropriately arranged to ensure the quality and accuracy of the results. IBM's Statistical Package for Social Sciences (SPSS) version 22.0 was used in this research to interpret and analyze the data, which were collected through Google Forms and then tested in relation to descriptive statistics, reliability analysis, factor analysis, and multiple regression analysis.

\section{Descriptive Analysis}

Descriptive statistics is a method often used to summarize a given data frequency, measures of central tendency, measures of dispersion or variation, and measures of position. The descriptions of the population are then presented in tables or graphs or as numerical calculations. By using descriptive statistics, a simple summary of the sample and measures can be formed. Frequency analysis is a part of descriptive statistics, and researchers often use this method to show the number of occurrences of each variable.

\section{Reliability Test and Factor Analysis}

A reliability test is an indicator to measure internal consistency. It is used to test whether the data or results are reliable and reproducible. Two important aspects are needed in conducting this research, namely reliability and validity. Reliability is the consistency of a test in giving a consistent answer over time. A reliability analysis is determined by obtaining the proportion of a systematic variation on a scale. The results and data collected for this research are considered valid when the measurement procedures are reliable. Validity can be defined as the accuracy or quality of a measurement. A test may not provide a valid measure even if it is reliable; however, a test cannot be counted as valid unless it is reliable.

A large number of variables can be reduced to a small number of constructs by using factor analysis. The maximum common variance is hereby extracted from all variables, placing them onto a common score. Confirmatory factor analysis (CFA) and exploratory factor analysis 
(EFA) are the two common types of factor analysis. EFA is a technique with the overarching goal of determining the underlying relationships between the measured variables. It is used when the number of factors existing among the variables is unknown. CFA is usually used in social research to test whether the measures of a construct are consistent with the researcher's understanding of nature. For the purpose of this study, the EFA technique is employed to assess the factors that determine the intention of Generation Z to use the Grab e-hailing service.

\section{Multiple Regression Analysis}

To determine the linear relationship between a dependent variable and the independent variables, multiple linear regression is a suitable method. In this case, this included four aspects, namely perceived convenience, perceived price and advantages, perceived accessibility, and perceived safety and security, which were analyzed and tested based on the questionnaire and in relation to the dependent variable, which is the behavioral intention of Generation $Z$ to use the Grab e-hailing service in UNIMAS. The calculated $R^{2}$ is used to measure the strength of the relationship between an independent variable and the dependent variable. The value of $R^{2}$ is in the range of 0 to 1 ; if the result of $R^{2}$ is close to 1 , it means that the relationship between the independent variable and the dependent variable is strong.

\section{Findings}

\section{Demographic Respondents}

There is a total of 330 sets of questionnaires were distributed to Third Year undergraduate students from Faculty of Economics and Business, UNIMAS. The return rate was $100 \%$ and all the results were used and analysed in this study. Demographic profile of respondents was presented with different characteristics groups include gender, age, residence, main transportation mode to university, average time taken and distance to get into university and others. Male is the majority of respondents who involved in this survey. There are 179 respondents or $54.2 \%$ of respondents were male. There were 151 out of 330 respondents or $45.8 \%$ of female respondents were participated in this survey. there are 212 respondents or $64.2 \%$ of respondents are 23 years old. For respondents that are 24 years old, there are 67 respondents out of 330 or $20.3 \%$ while 25 respondents or $7.6 \%$ aged 22 . For age 25 , it included 23 respondents or $7 \%$ while only 3 respondents aged 21 or $0.9 \%$. Among 330 respondents, there are 174 respondents or $52.7 \%$ require approximately $1-3 \mathrm{~km}$ to get into UNIMAS. There are 72 respondents or $21.8 \%$ require approximately $3-5 \mathrm{~km}$ to get into UNIMAS. There are 53 respondents or $16.1 \%$ require less than $1 \mathrm{~km}$ to get into UNIMAS, whereas there are only 15 respondents or $4.5 \%$ take approximately 5 $10 \mathrm{~km}$ and lastly 16 respondents or $2.8 \%$ take more than $10 \mathrm{~km}$ to get into UNIMAS.

\section{Reliability Test and Factor Analysis}

The total variance explained is 59.405\%. The Kaiser-Meyer-Olkin Measure of Sampling Adequacy is 0.847 , which is higher than 0.6. The Bartlett's Test of Sphericity is 2687.02 and the chi-square 
is statistically significant. According to the Rotated Component Matrix ${ }^{a}$, perceived price and advantages is the main factor in explaining the intention of Generation Z to use the Grab e-hailing service as the variance is $19.912 \%$. Hence, the price of the Grab e-hailing service is considered reasonable and affordable. The Grab e-hailing service also offers lower prices compared to traditional taxis. The respondents also stated that there are no or very little charges for using the Grab e-hailing service.

Next, perceived convenience has a variance of $15.864 \%$, which is another factor in explaining the intention of Generation $Z$ to use the Grab e-hailing service. Most of the respondents stated that they save time and effort by using the Grab e-hailing service, and they are able to reach their destination on time. The Grab payment transaction is convenient, and the Grab app's navigation is easy. In addition, perceived accessibility is another factor to explain the intention of Generation Z to use the Grab e-hailing service. Perceived accessibility has a variance of $13.809 \%$. The respondents stated that they are able to get the latest information about Grab from various channels, and they can also get a car very quickly in the UNIMAS area. Lastly, perceived safety and security is a minor factor to explain the intention of Generation $Z$ to use the Grab e-hailing service. It has a variance of $9.819 \%$. Most of the respondents felt that using the Grab e-hailing service while on a night out is less safe. The credit card details and personal information are also considered to be less secure when connected with the Grab application.

Table 1: KMO and Bartlett's Test

KMO and Bartlett's Test

Kaiser-Meyer-Olkin Measure of Sampling Adequacy.

Bartlett's Test of Sphericity

Approx. chi-square

.847

df

2687.020

Sig.

.000

\section{Reliability Test}

The value of Cronbach's coefficient is presented for each construct. This shows an acceptable result for reliability. The Cronbach's alpha in this study regarding the perceived safety and security is 0.807 ; perceived price and advantages is 0.811 ; perceived convenience is 0.724 ; and perceived accessibility is 0.785 .

\section{Table 2: Reliability Test}




\begin{tabular}{|c|c|c|c|}
\hline Constructs & $\begin{array}{l}\text { Measurement } \\
\text { Items }\end{array}$ & Reliability & $\begin{array}{l}\text { Number } \\
\text { Items }\end{array}$ \\
\hline \multirow[t]{5}{*}{ Perceived safety and security } & SS1 & 0.807 & $5(5)$ \\
\hline & SS2 & & \\
\hline & REV_SS3 & & \\
\hline & SS4 & & \\
\hline & SS5 & & \\
\hline \multirow[t]{5}{*}{ Perceived price and advantages } & REV_PA1 & 0.811 & $5(5)$ \\
\hline & PA2 & & \\
\hline & REV_PA3 & & \\
\hline & PA4 & & \\
\hline & PA5 & & \\
\hline \multirow[t]{5}{*}{ Perceived convenience } & $\mathrm{C} 1$ & 0.724 & $5(5)$ \\
\hline & $\mathrm{C} 2$ & & \\
\hline & C3 & & \\
\hline & $\mathrm{C} 4$ & & \\
\hline & $\mathrm{C} 5$ & & \\
\hline \multirow[t]{4}{*}{ Perceived accessibility } & A1 & 0.785 & $4(4)$ \\
\hline & $\mathrm{A} 2$ & & \\
\hline & A3 & & \\
\hline & A4 & & \\
\hline
\end{tabular}

\section{Multiple Linear Regression Analysis}

The multiple linear regression data results show that the relationships between the dependent and independent variables are weak; the $\mathrm{R}^{2}$ value is 0.467 , which means that $46.7 \%$ of the independent variables (perceived safety and security, perceived price and advantages, perceived convenience and perceived accessibility) can be explained by the dependent variable (behavioral Intention). An $\mathrm{R}^{2}$ value lower than $50 \%$ is as expected in the field of human behavior.

\section{Table 3: $\mathbf{R}^{2}$ value}

\begin{tabular}{|c|c|c|c|c|c|}
\hline Model & $\mathrm{R}$ & R-square & $\begin{array}{l}\text { Adjusted R- } \\
\text { square }\end{array}$ & $\begin{array}{l}\text { Std. error of } \\
\text { the estimate }\end{array}$ & $\mathrm{F}$ \\
\hline 1 & $.684^{a}$ & .467 & .461 & .46098 & 71.246 \\
\hline
\end{tabular}

a. Predictors: (Constant), ta, tss, tpa, tc

\section{Hypothesis Testing}

The hypotheses were tested using multiple linear regression. Four hypotheses were developed in this research examining the relationship between the four perceived variables (perceived safety and security, perceived price and advantages, perceived convenience, and 
perceived accessibility) and the intention of Generation Z to use the Grab e-hailing service. It was found that only three hypotheses (perceived price and advantage, perceived convenience, and perceived accessibility) are supported in explaining the intention of Generation Z to use the Grab e-hailing service. The $B$ coefficient for perceived price and advantages is 0.538 , thus it has the greatest impact on the intention to use the Grab e-hailing service among the independent variables. This is followed by perceived convenience, which has a $B$ coefficient of 0.118 , while perceived accessibility has a $B$ coefficient of 0.100 . Perceived safety and security is not a significant factor determining the intention of Generation $Z$ to use the Grab e-hailing service, meaning that Hypothesis 1 is rejected.

Table 4: Hypotheses Output

\begin{tabular}{llll}
\hline Hypothesis & $\begin{array}{l}\text { Beta } \\
\text { Coefficients } \\
(\boldsymbol{\beta})\end{array}$ & t-values & Results \\
\hline $\begin{array}{l}\text { Perceived safety and security } \rightarrow \\
\text { Intention of using e-hailing services }\end{array}$ & 0.078 & 1.545 & Not Supported \\
$\begin{array}{l}\text { Perceived price and advantages } \rightarrow \\
\text { Intention of using e-hailing services } \\
\text { Perceived convenience } \rightarrow \text { Intention } \\
\text { of using e-hailing services }\end{array}$ & 0.538 & 11.280 & Supported \\
$\begin{array}{l}\text { Perceived accessibility } \rightarrow \text { Intention } \\
\text { of using e-hailing services }\end{array}$ & 0.100 & 2.307 & Supported \\
\hline
\end{tabular}

\section{Conclusion}

This study has attempted to determine the main underlying variables of the intention to use e-hailing services among Generation Z. It is evident that three of the perceived variables, namely perceived price and advantages, perceived convenience, and perceived accessibility, are statistically significantly to the behavioral intention of Generation $Z$ to use the Grab e-hailing service. Hereby, perceived price and advantages is the dominant factor influencing the UNIMAS students' intention. The factors of perceived ease of use and perceived usefulness also indicate that the users are satisfied with the Grab application platform. Moreover, the respondents were least satisfied with perceived safety and security, meaning that the safety and security dimension is a major limitation of the intention of Generation Z to use the Grab e-hailing service in UNIMAS. Therefore, this research suggests for continuous improvement and upgrades on its safety policy to protect the safety of both the customers and their personal information especially in this digital era. As the study highlighted the perceived price and advantages as the main determinant, it is vital for Grab e-hailing services to take note that youth are very sensitive to changes in price. Therefore, it is worthy to consider a certain price structure targeting not only on youth but other special interest group of people including the elderly and the disable. Furthermore, a specified 
INTERNATIONAL JOURNAL OF ACADEMIC RESEARCH IN BUSINESS AND SOCIAL SCIENCES

Vol. 9, No. 11, November, 2019, E-ISSN: 2222-6990 @ 2019 HRMARS

Grab e-hailing services (trained and licensed) may also be provided to cater for these people with special needs which may increase the confidence and the market positions of Grab as one of the leading providers in the region.

\section{Acknowledgement}

The authors acknowledge the financial support from Universiti Malaysia Sarawak (UNIMAS). All remaining flaws are the responsibilities of the authors.

\section{References}

Abboud, L., \& Wagstaff, J. (2015). Legal troubles, market realities threaten Uber's global push. Ajzen, I. (1971). Attitudinal vs. normative messages: An investigation of the differential effects of persuasive communications on behavior. Sociometry, 34, 263-280.

Ajzen, I. (1991). The theory of planned behavior. Organizational Behavior and Human Decision Processes, 50, 179-211.

Bell, E., \& Bryman, A. (2007). The ethics of management research: an exploratory content analysis. British Journal of Management, 18(1), 63-77.

Bills to legalise Grab, Uber tabled in Malaysian Parliament. (2018). Retrieved from https://www.todayonline.com/world/asia/uber-grab-rides-could-be-legalised-soonmalaysia

Budiono, O. A. (2009). Customer satisfaction in public bus transport: A study of travelers' perception in Indonesia. Master's thesis, Service Science Program, Karlstad University.

Button K. J., \& Hensher D. A. (2001). Handbook of logistics and supply-chain management, 3rd Ed. Emerland Group: UK.

Charles, G. (2013). Generation Y will end UK's 'love affair' with car ownership, claims study. Retrieved 10 February 2016, from http://www.marketingmagazine.co.uk/article/1222278/generation-y-will-end-uksloveaffair-car-ownership-claims-study

Charo, N., Sharma, P., Shaikh, S., Haseeb, A., \& Sufya, M. Z. (2015). Determining the impact of EWOM on brand image and purchase intention through adoption of online opinions. International Journal of Humanities and Management Sciences, 3(1), 41-46.

Charoen, D. (2015). Grabtaxi: A taxi revolution in Thailand. International Journal of Management and Applied Science, 1(9), 154-157.

Clewlow, R. R., \& Mishra, G. S. (2017). Disruptive transportation: The adoption, utilization, and impacts of ride-hailing in the United States. University of California, Davis, Institute of Transportation Studies, Davis, CA, Research Report UCD-ITS-RR-17-07.

Deloitte Global. (2014). Generation $Y$ in Europe I Deloitte I Press release, vehicles, Smartphones \& Technology. Retrieved 10 February 2016, from http://www2.deloitte.com/global/en/pages/aboutdeloitte/articles/generation-y-ineurope.html 
Ferrarese, M. (2018). Uber \& Grab are better than Taxis in Penang | Penang Insider. Retrieved from https://www.penang-insider.com/why-uber-grab-are-better-than-taxis-in-penang/

Fleischer, A., \& Wåhlin, C. (2016). Want to Take a Ride with Me?: The Intention of Generation Y to Use Uber.

Goldman Sachs. (2016). Millennials Infographic. Retrieved 9 May 2016, from http://www.goldmansachs.com/our-thinking/pages/millennials/

Gollwitzer, P. M. (1999). Implementation intentions: Strong effects of simple plans. American Psychologist, 54, 493-503.

Griswold, A. (2016). The biggest legal threat to Uber's business just got a whole lot bigger. Retrieved from http://qz.com/570167/the-biggest-legal-threat-to-ubers-business-justgota-whole-lot-bigger/

He, F., Wang, X., Lin, X., \& Tang, X. (2018). Pricing and penalty/compensation strategies of a taxi-hailing platform. Transportation Research Part C: Emerging Technologies, 86, 263279.

Herath, S. (2014). The impact of in-store environment on the impulse buying behavior in supermarkets in Sri Lanka. University of Sri Jayewardenepura.

Horsu E. N., \& Yeboah S. T. (2015). Influence of service quality on customer satisfaction: A study of minicab taxi services in Cape Coast, Ghana. International Journal of Economics Commerce and Management, 3(5), 1-14.

Hox, J. J., \& Boeije, H. R. (2005). Data collection, primary versus secondary.

Khairani, I. \& Hati, S. R. H. (2017). The effects of perceived service quality towards customer satisfaction and behavioral intentions in online transportation. International Journal of Humanities and Management Sciences, 5(1),1-5.

Jalilvand, M. R., \& Samiei, N. (2012). The effect of electronic word of mouth on brand image and purchase intention. Marketing Intelligence \& Planning, 30(4), 1-11.

Or, K. and Amichai-Hamburger, Y. (2008). The effects of cognition on internet use revisited. Computers in Human Behavior, 24(2), 361-371.

Kazmi, A. \& Mehmood, Q. S. (2016). The effect of electronic word of mouth communication and brand image on purchase intention: A case of consumer electronics in Haripur, Pakistan. Management Science Letters, 6, 499-508.

Khuong M. N., \& Dai N. Q. 2016. The factors affecting customer satisfaction and customer loyalty: A study of local taxi companies in Ho Chi Minh City, Vietnam. International Journal of Innovation, Management and Technology, 7(5).

Kotler P. \& Keller K. (2006; 2009). Marketing management, 12th Edition. Pearson Education Inc: New Jersey.

Kumar P.K., \& Kumar N.R. (2016). A study on factors influencing the consumers in selection of cab services. International Journal of Social Science and Humanities Research, 4, 3, Pp: (557-561).

Ladipo, P. K. A., Nwagwu, K. O., \& Alarape, W. B. (2013). Relative communication power of selected advertising media. International Business and Management, 6, 77-87. 
Lai, W. T. \& Chen, C. F. (2010). Behavioral intentions of public transit passenger: The role of service quality, perceived value, satisfaction and involvement. Transport Policy.

Landau, S., \& Everitt, B. S. (2004). Analysis of repeated measures II: Linear mixed model. In: A handbook of statistical analysis using SPSS (pp. 194-215). Boca Raton, FL: Chapman \& Hall.

Lee Taylor, S., \& Cosenza, R. M. (2002). Profiling later aged female teens: mall shopping behaviour and clothing choice. Journal of Consumer Marketing, 19(5), 393-408.

Lin, C., Wu, Y., \& Chen J. V. (2013). Electronic word-of-mouth: The moderating roles of product involvement and brand image. Technology Innovation and Industrial Management, 2947.

Lin, M., \& Dula, C. (2016). Grab taxi: Navigating new frontiers. Asian Management Insights, 3(6), 40-45.

Litman, T. (2008). Valuing transit service quality improvements. Journal Of Public Transportation, 43-64.

Lovelock C. H., \& L. (2002). Principles of service marketing and management. Prentice Hall.

Malhotra, N. K., Birks, D. F., Wills, P. (2012). Marketing research: An applied approach, 4th ed.

Mburu P., Zyl H. V., \& Cullen M. (2013). Determinants of customer satisfaction in the Kenyan banking industry. European Journal of Business and Management, 5(2), 1-8.

Mcknight, C. E., Pagano, A. N., \& Paaswell, R. E. (1986). Using quality to predict demand for special transportation. In: Behavioral research for transport policy. International Conference on Travel Behaviour, Noordwijk, the Netherlands, Utrecht: VNU Science Press.

Mohan, G., Sivakumaran, B., \& Sharma, P. (2013). Impact of store environment on impulse buying behavior. European Journal of Marketing, 47(10), 1711-1732.

New Straits Times. (2017). Grab Malaysia receives e-money licence. Retrieved from: https://www.nst.com.my/business/2017/12/312351/grab-malaysia-receives-e-moneylicence

Shintaro, O., Akihiro Katsukura, A., and Nishiyama, M. (2007). How mobile advertising works: The role of trust in improving attitudes and recall. Journal of Advertising Research, 47(2), 165-178.

Oliver, R. (1980). A cognitive model of the antecedent and consequences of satisfaction decisions. A Journal of Marketing, 17(10), 460-469.

Parasuraman A. Zeithaml, V., \& Berry, L. L. (1985). A conceptual model of service quality and its implications for future research. Journal of Marketing, 49(4), 4150.

Pallant, J. (2013). SPSS survival manual. McGraw-Hill Education (UK).

Payne, A. A. (2005). A strategic framework for customer relationship management. Journal of Marketing, 69, 4, 167-76.

Pikri, E. (2018). Uber's almost gone, so here're 6 other ride-hailing options in M'sia. Retrieved from https://vulcanpost.com/637030/ride-hailing-competitor-malaysia-grab/

Polkinghorne, D. E. (2005). Language and meaning: Data collection in qualitative research. Journal of Counseling Psychology, 52(2), 137.

Prasad, S., Rao, A., \& Rehani, E. (2001). Developing hypothesis and research questions. 
Reinartz, W., Krafft, M., \& Hoyer, W. D. (2004). The customer relationship management process: Its measurement and impact on performance. Journal of Marketing Research, 41, 3, 293-305.

Salkind, N. J. (2012). Exploring research, 8th Edition. New Jersey, NY: Pearson.

Samson, R., \& Thompson, P. (2007). Passenger focus. Warrington, UK: Free Post.

Saunders, M., Lewis, P., \& Thornhill, A. (2009). Research methods for business students. Pearson education.

Schultz, D., Jain, V., \& Viswanathan, V. (2015). Differential Gen Y's World of Apps. Marketing News, 49(8), 14.

Smith, K. T. (2011). Digital marketing strategies that Millennials find appealing, motivating, or just plain annoying. Journal of Strategic Marketing, 19, 489-499.

Sulistiyarini, S. (2012). Pengaruh Minat Individu Terhadap Penggunaan Mobile Banking: Model Kombinasi Technology Acceptance Model (TAM) dan Theory of Planned Behavior (TPB). 28.

Thaler, R. H., \& Tucker, W. (2013). Smarter information, smarter consumers. Harvard Business Review, 91(1), 44-54.

Torlak, O., Ozkara, B. Y., Tiltay, M. A., Cengiz, H., \& Dulger, M. F. (2014). The effect of electronic word of mouth on brand image and purchase intention: An application concerning cell phone brands for youth consumers in Turkey. Journal of Marketing Development and Competitiveness, 8(2), 61-68.

Tuttle, B., \& Tuttle, B. (2012). Will Gen y lead the shift from gas-powered cars to hybrids and electric vehicles? | TIME.com. TIME.com. Retrieved 10 February 2016, from http://business.time.com/2012/01/24/will-gen-y-lead-the-shift-from-gas-powered-carsto-hybrids-andelectric-vehicles/

Vahdati, H., \& Nejad, S. M. (2016). Brand personality toward customer purchase intention: the intermediate role of electronic word-of-mouth and brand equity. Asian Academy of Management Journal, 21(2), 1-26.

Valenzuela, S., Park, N., \& Kee, K. F. (2009). Is there social capital in a social network site?: Facebook use and college students' life satisfaction, trust and participation. Journal of Computer-Mediated Communication, 14(4), 875-901.

Weatherhead, R. (2014). Say it quick, say it well - the attention span of a modern internet consumer. The Guardian. Retrieved 22 March 2016, from http://www.theguardian.com/media-network/medianetworkblog/2012/mar/19/attention-span-internet-consumer

Wong, A. (2018). This is probably the next best alternative to Grab in Malaysia I SoyaCincau.com. Retrieved from https://www.soyacincau.com/2018/04/05/mycar-ridehailing-alternative-to-grab-uber-in-malaysia/

Yelkur, R. (2000). Customer satisfaction and the services marketing mix. Journal of Professional Service Marketing, 21(1).

Yoo, B., \& Donthu, N. (2001). Developing and validating a multidimensional consumer-based brand equity scale. Journal of Business Research, 52, 1-14. 
INTERNATIONAL JOURNAL OF ACADEMIC RESEARCH IN BUSINESS AND SOCIAL SCIENCES

Vol. 9, No. 11, November, 2019, E-ISSN: 2222-6990 @ 2019 HRMARS

Zhang, T., Omran, B. A., \& Cobanoglu, C. (2017). Generation Y's positive and negative eWOM: Use of social media and mobile technology. International Journal of Contemporary Hospitality Management, 29(2), 732-761. 